\title{
ALTIN VE DOLAR BUHRANI
}

\section{G. GeLebican}

Son on yıl içinde uzun boylu tartışılan «milletlerarası likidite» meselesi iki kısma aynlabilir: Milletlerarası ticaret ve tediyelerin bugüinkï hacmi ile demirperde dışındaki memleketlerin sahip bulunduklan dıs ihtiyatlar arasındaki nisbet kâfi ve tatminkâr addedilebilir mi? Milletlerarası likiditenin dünya ticaretinin gelişme bzına uygun olarak artırılmasi mümkün müidür? Profesör Triffin, 1960 yılı sonlannda yayınladıgr kitabında: (1), bu iki soruya cevap aramaktadir.

Dıs ihtiyatlarn dünya ticaret hacmine nisbetle, istenilen seviyede bulunmadığı, bugün hemen hemen tartışmasız kabul olunmaktadır. Nitekim Dr. Triffin de, $1950-, 57$ yilları arasinda devletlerin, yllik ithalât kiymetinin en az \% $40^{\prime}$ ' kadar dış ìtiyatlara sahip olduklarm belirttikten sonra, 1957 yll sonunda A.B.D. ile Birleşik Krallık dışındaki hür memleketlerde bu nisbetin ancak $\% 35 \mathrm{e}$ eriştiğine işaret etmektedir.

Dış ihtiyatlarm yetersiz bulunuşu, milletlerarası ticaret ve tediyeler ile dış ihtiyatlar hacmi arasındaki bugünkü nisbetin arzu edilen seviyeye çkanlmasını gerekli kılmaktadır. Diğer taraftan, «arzu edilen seviyenin» muhafaza edilebilmesi, dıs ihtiyatlann, dünya ticaretindeki gelişmeye uygun olarak artırilmasın icap ettirméktedir.

Bugünün şartlan içinde, dış thtiyatlanı artınlması, Sovyetler Birliğinin her yl dünya piyasasına sürdügüi altının ve hür dünyadaki yıllık altın istihsalinin kullanılmasiyla mümkün olabilir. Di-

(1) R. TRIFFIN : Gold and Dollar Crisis. The Future of Convertibility: Yale University Press, New Haven 1960, xili +195, \$4.78. 
ger bir imkân da, milletlerarası tediyelerde kullanılan gevrilebilir (convertible) yabancı paraların gittikçe artan miktarlarda ihtiyatlara dahil edilmesidir. Birinci imkânın, dış ihtiyatların artmasına önemlli derecede yardm etmesi beklenemez. Gerçekten de dünya alton istihsali, ihtiyaca nisbetle son derecede azdrr. Yillik altın arzınin önemli bir kism sanayide kullanimakita veya fertler tarafindan iddihar edilmektedir. Nitekim, 1950-57 yılları arasinda A.B.D. dışındaki hür memleketlerin dış ihtiyatlarındaki artısıın ancak $\% 36$ sını altın teşkil etmiştir. Keza, 1938'de A.B.D. ile Birleşik Krallık dışındaki memleketlerin elinde bulunan dıs ihtiyatlann $\% 82$ 'si altrn olduğu halde bu nisbet 1957 ' dè $\%$ 45'e düşmüs bulunmaktadır. Şu hale göre, dış ihtiyatların artırılması için kullanılabilecek tek yol, dolar ve sterlin gibi dünya ticaretinde kullanlan paraların gittikçe çoğalan miktarlarda ihtiyat olarak tutulmasıdır. Fakat bu imkânın da dünya likiditesini arturmakta yapacağ yardım sınırlıdır. Çünkï hiç bir devlet, parasınnn başka memleketlerce hudutsuź olarak biriktirilmesine, böylece «sâfi dı̣ ihtiyatiar» durumunun sarsılmasina müsaade edemez. Aksi halde, muayyen bir hadden sonra parasi yeter derecede sağlam addedilmeyecek ve daha emin görülen başka bir devlet parasına veya altına kaçı̧ baş gösterecektir. Bunun neticesi, 1931'de Ingiltere'yi altn kambiyo standardindan aynılmak zorunda brrakan kaçışta olduğu gibi, deflâsyon, devalüasyon ve dıs ticaret tahditlerinin dünyaya yayılması olacaktrr.

$O$ halde, hem milletlerarasi ihtiyatlan istenilen seviyeye gskartmak, hem de milletlerarası tediyeler sisteminin istikrann muayyen bir veya bir kaç «kilittaşı millî paraya beslenen itimada bağlt olmaktan kurtarmak için ne yapmalıdrr? Profesör Triffin, sonuyu Bretton Woods Konferans'na sunulan ve «Keynes Plânı» (2) olarak tannan Ingiliz teklifini canlandumak suretiyle cevaplandırmaktadır :

Devletler, ellerinde bulunan dis ihtiyatların muayyen bir kısmın milletlerarası bir müesseseye -Triffin, Milletlerarası Para Fonunun bu maksatla bir milletlerarası merkez bankası haline getirilmesini teklif etmektedir- devretmeli ve kendi mevduat hesaplan ile diger devletlerin hesaplan arasinda yaplacak aktarmalan hudutsuz olarak kabul etmelidirlen Milletlerarası Para Fonundaki

(2) Proposals for an International Clearing Union, Cmd. 6437, 1948. 
mevduat, her bakımdan altına eșit kabul ve farz olunmalıdır. MPF., herhangi bir banka gibi, devletlere keşide hakkı tanımak suretiyle milletlerarası likiditenin istenildiği kadar artmasına imkân verebilecektir. Hudutsuz olatak açlacak kredinin yaratabileceği dünya çapinda bir enflâsyon tehlikesini bertaraf etmek için Dr. Triffin MPF. nun kredi açma yetkisinin, diş ihtiyatlarda ylda \% 3 ilâ 5 (veya önceden tespit edilecek herhangi bir nispet) kadar bir artışa vüicut verecek şekilde sınırlandınlmasını yeter görmektedir. Profesör Triffin'e göre, devletlerin, ellerindeki gayri sâfi ihtiyatlann $1 \% 20$ sini MPF. na tevdi etmeleri, milletlerarasi tediyelerin yapilmasina yetecektir. Herhangi bir devletin Fon'daki mevduat bu miktarı aştı̆ğ takdirde, karşılığını̣ altın olarak almak hakkı vardır.

Bu sistemin üstün tarafı, dünya dış ihtiyatlar hacminde vuku bulacak her artısıı, otomatik olarak MPF. mevduatına tahvil etmesinde; bilhassa ihracatı en fazla olan ve dolayısiyla parası en cok aranan devleti, en büyük tevdiatı yapmak zorunda bırakmasındadir.

Teklif ettiği sistemin son safhası olarak Triffin, devletlerin dıs ihtiyat olarak sakladiklan yabancı memleket paralarımn tamamint MPF. na yatırmalannı istemektedir. Ancak bu noktada yazar, bir hayli müphem kalmakta ve devletlerin hangi saikle döviz ihtiyatlan üzerindeki kayıtsız tasarruf imkânlanndan vaz geçeceklerini izah etmemektedir. Devletlerin, bu yoldaki karşllıklı ve iradî feragatleri veya MPF. nun mevduata verecegri yüksek faiz ihtimalleri, kitabın başka kısımlarında verilen izahata uygun düşmektedir.

Dış ihtiyatların bu suretle milletlerarası duruma'getirilmesi, milletlerarası likiditenin, dünya ticaretinin gelişme hızına uygun olarak artmasını sağlıyacağı gibi, milletlerarası tediyeler sistemini bir veya birkaç «kilittaşı» paraya iștinat etmekten de kurtaracaktrr.

Profesör Triffin'in kitabr, yukarda da belirtilldiği gibi, dünya likiditè meselesine yeni çözüm şekilleri getirmemektedir. Diğer taraftan, yazann milletlerarası likiditeniri yeterliłi hakkındaki görüşï fazlaca karamsar addedilebilir. Gerçekten kitapda, dış ihtiyatlanın çoğalmasının, ancak A.B.D. ile Ingiltere'nin kısa vâdeli borçlannın artması halinde mümkün olacağı farz olunmaktadır. Halbuki, kitabın bitirildiği tarihten (1959) bir kaç ay evvel çevrilebilir (convertible) hâle getirilmiş olan belli başlı Avrupa paralan, mil- 
letlerarası likiditenin antmasına süuphesiz yardım edebileceklerdir. Onemli Avrupa paralannın çevrilebilirliği (convertibility), altun, dolar ve sterline ilâveten Mark, Belçika Frank'ı ve Hollanda Guilder'i veya Fransız Frank'mın ihtiyat akçesi olarak kullanı̇masına yol açabilir. Şüphe yok ki, bu paralann dünya likiditesine yapacaklan yardım, ilgili memleketlerin milletlerarası ticaretteki önemleri ile sinırI olacaktrs.

Milletlerarası likiditenin bugünkï durumu, Triffin'in gördügüi kadar endise verici addedilmese dahi, her hangi bir sebeple itimatun sarsilmast halinde, ihtiyat akçesi olarak tutulan muhtelif paralar arasında geniş aktarmalar olacağı, neticede gerek parasından kaçlan memleket ekonomisinin gerekse dünya ticaretinin büyük zarar göreceği muhakkaktrr. Ancak, bu tehlikeye isaret ederken yazar, yine fazlaca karamsar görünmektedir. Gerçekten milletlerarası iktisadî işbirliginin, 1930 yılların tekrarlatmyacak kàdár ilerledigini iddia etmek mübalâga addedilmemelidir. 1960 ylında dolann, 1961 de sterlin'in maruz kaldığg büyük spekülâtif baskılar, yurtiçi para siyaseti ve milletlerarasındaki karşllıkh işbirliği ve yardmmlašma yoluyla hafifletilebilmiştix. Dolar ve sterlin'den büyüik ölçüde ve devamlı kaçıs olmasına rałgmen, Triffin'in endişeleri tahakkuk etmemiştir.

Dış ihtiyatlann yeterlik derecesini tâyin ederken gözden kaçınlmaması gereken bir nokta, milletlerarası ticaretin tâbi bulundugu tahdit ve kontrollårdur. Milletlerarası ticaret ve tediyeler üzerindeki tahditler şiddetli olduğu nispette, diş ihtiyatlara duyulan ihtiyaç az olur. Dünya ticaretinin gittikçe tahditlerden kurtulduğu göz önüne alıırsa, diş ihtiyatlar ihtiyacmın yakın gelecekte daha da büyük olacağı söylenebilir. Bu suretle Profesör Triffin'in teklifi, uzun vâdede kendini şiddetle hissettirecek bir ihtiyaca önceden cevap teşkil etmektedir. Diǧger taraftan, milletlerarası iktisadi işbirliğinin daha çok gelişmesini ve dünya çapında bir iktisadì tamamlanma hareketinin başlamasımı dileyenlerin, Triffin Plân'ına taraftar olacağı șüphesizdir. 